\title{
STUDY OF PHENOMENOLOGY-HERMENITIC ON SUNDANESE VERNACULAR ARCHITECTURE PUBLIC SPACE
}

\author{
Nuryanto1; Sri Rahaju B.U.K. ${ }^{2}$; Indah Widiastuti ${ }^{3}$
}

1 Department of Architectural Engineering Education, Universitas Pendidikan Indonesia, Bandung, Indonesia

2, 3 Department of Architecture, SAPPK Institut Teknologi Bandung, Indonesia

Corresponding Author: nuryanto adhi@upi.edu, srirahaju@sappk.itb.ac.id, widiastuti@sappk.itb.ac.id

Received: 13 April

Revised: 18 April 2020

Article History: 2020 Accepted: 24 Apri; 2020

Available online: 30 April 2020

\begin{abstract}
This research is motivated by the phenomenon of inter-building space which is understood as an open area and can be accessed by people who are usually located between buildings. This study is a case study on public spaces in kampung Kasepuhan Ciptarasa and Ciptagelar, Sukabumi-West Java. The space between buildings in this study is interesting because in it public activities and rituals on a community scale can be held which are quite limited. The community itself becomes the agent responsible for care. The purpose and significance of public space research lie in the disclosure of open space phenomena that are local and participatory. The research method used is phenomenology-hermeneutics to find out the meaning of interpretation of the text of a phenomenon of public space that occurs. The results showed that the use of public space for the residents of kampung Kasepuhan Ciptarasa and Ciptagelar due to ritual activities, especially Seren Taun. Beyond that, the function of public space is not visible. This reflects the position of the importance of the presence of public space only to facilitate the activities of the rite of the community.
\end{abstract}

Keywords: phenomenology-hermeneutic, text, public space, ritual, vernacular

\section{Introduction}

This research is a search for the complexity of the phenomenon 'activity space' contained in the form and form of public space. The public space that is the object of this research is the space facilities that are shared by members of the indigenous community in kampung Kasepuhan Ciptarasa and Ciptagelar. This research is exploratory by utilizing phenomenology-hermeneutic methods (approaches) in architecture and ethnography. Data is collected through measurement and recording of public space on village architecture and elements forming public spaces.

Phenomenological and ethnographic interviews were conducted to explore the meaning behind the visual language that was guarded. The analysis was carried out qualitatively to recognize visual language which includes material, scale, proportion, aesthetics, color, texture, detail, as expressions of creativity and the potential of the community to create meaningful means of social interaction. The results of this research are a continuation of the accumulation of knowledge about the local visual language as part of the archipelago visual language, which is different from Western rules.

\section{Method Phenomenology-Hermenitic Research}

Phenomenology is an interpretive study of human experience, aimed at understanding and explaining human situations, events, and experiences, "as something that arises and is present every day" (von Eckartsberg, 1998). The phenomenological approach is one of the innovative ways to view human relationships and the environment and explore the complexity of the relationship (Spradley, 
1980). The big challenge in the phenomenological approach is the description of the closeness of human-world closeness that is freed from the dichotomy of formal subject-objects. Behaviorenvironment expresses three ideas, namely: Lifeworld, place, and home, because these three aspects are of interest in making someone move in, and all three have a visible impact, namely physical, spatial, and environmental aspects of human life. (a) Lifeworld: refers to a complex of events, conditions, and context held in life and arranging the roles and relationships of the people in it. Lifeworld includes routine, unusual, ordinary and even surprising aspects. (b). Place: one of the important dimensions in lifeworld that refers to the human experience that is usually traced through direct expression and direct interaction with human actors. (c). Home: important aspects of lifeworld refer to the situation of closeness, poverty, and the attachment of humans to their world. Hermeneutics is the theory and practice of interpretation (Whyte, 1980), especially about the interpretation of texts, which may be material objects, palpable or unobservable and contain meaning. Examples of this text are public documents, personal journals, poems, songs, paintings, sculptures, parks, and so on. Architecture can also be seen on one side as work and at the same time as a text. As a work, architecture is a creation or engineering of the designer or maker. As a text, architecture is a contextual universe where meaning gets its interpretation in a particular architectural form. The environment becomes the context for the production and consumption of texts and is a factor for the emergence of "impartiality objectivity" (Eriyanto, 2001). Architectural embodiment and disclosure are languages that produce texts and works. Knowledge constructed in language can be justified in its validity and equality, with a note as the ontology or philosophy underlying the language used (Poespoprodjo, 1987).

In principle, hermeneutic analysis activities are carried out through two activities, namely: the activity of translation and the activity of interpretation, which is the main key to research texts or works. The technical research design will be carried out as follows: First: Translation; carried out by decomposition and re-election (recomposition) into new categories of knowledge based on variables and frequencies in the interface spaces. This variable was chosen based on facts, namely public activities, intensive gathering and discussion carried out in these spaces, and a model of renewing the tradition of activities in local community spaces. The objects to be seen are two, namely: (1). Patterns of functional community activities and equipment used, such as trading, weaving, storing, chatting, and ritual activities; (2) Behavioral settings (behavioral settings, territoriality, milieu), for example: in spaces or alleys between buildings, in the field, and around public buildings. Second: Interpretation; This is done by interpreting texts that are inherent in the patterns of functional and regulatory activities, including the spatial patterns of activities in the spatial profile typology of public activities that occur on the outside, user or participant experience, integration, and time activities. Third: Reading; carried out by stringing various elementary categories and elementary interpretations carried out on the translation to interpretation, and will be derived from the norms, principles, technical aspects, and contextual design that forms the background of the formation of a tradition of outdoor activities.

\section{Result and Discussion}

\subsection{Community Activities in Kampung Kasepuhan Ciptagelar}

Community activities that appear on the big road (jalan gede) are chatting and gathering in the middle of the road, children playing, and so forth. This can be seen especially in the afternoon when residents come home from work. They often stand relaxed even squatting, starting from the edge to the middle of the road. According to residents, standing relaxed, hanging out and squatting on the streets feels fun, good, and relaxed; the important thing is not to disturb people and passing vehicles. Activities in the bumi ageung field (great house), people drying the grain, several parking cars, children playing, some people sitting on the bale (edge) of the meeting hall waiting for the car to cross the field to kampung Kasepuhan Ciptagelar while chatting, smoking, and waiting for the product to be donated for a celebration (fig. 1). Some teenagers play volleyball, and another group of teens watches on the sidelines while chatting. Many women's activities in saung lisung while pounding their rice chatting, waiting their turn and winnowing, so the atmosphere is very crowded. In the space between buildings, women are also often seen chatting with neighbors of the house, because the distance is very close $(120-200 \mathrm{~cm})$. Activities in the toilet especially washing are done by women while chatting and bathing children. 


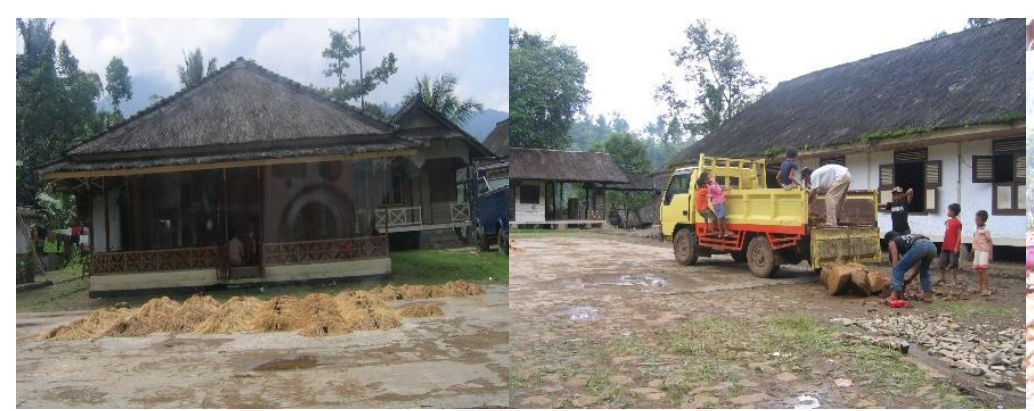

Drying rice in the yard

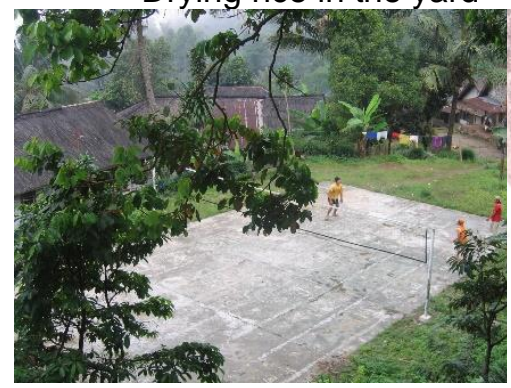

Playing volleyball on field

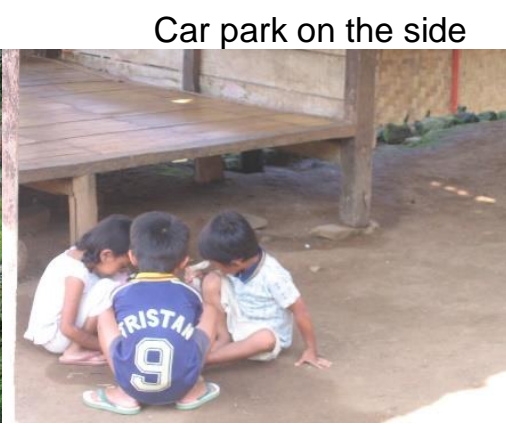

Children playing

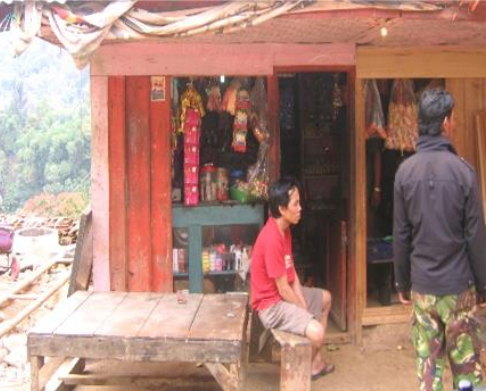

Chat in a stall

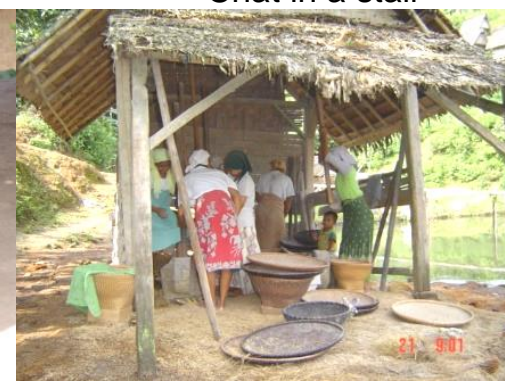

Woman wearing rice

Figure. 1: Spaces that are often used as activities by residents.

Source: Research tim, 2019

Activities at tepas imah (terrace) are resting, sitting, lying down while listening to music, chatting, and receiving guests (fig. 2). Some forms of activities that they usually do every day include: ngadongeng, ngawangkong, ngabungbang, and sisiaran. Ngadongeng is a story about the past. Ngawangkong, namely telling stories without a clear title; "teu huluan, teu buntutan" means without a title or conclusion. Ngabungbang is gathering on the porch of the house with family or closest relatives on a full moon night while copying and smoking. While the sisiaran is cleaning the hair from dust and lice done by mothers. Activities in the pawon (kitchen) in the morning and evening are carried out by mothers to prepare food for their families. During the day, the pawon are quiet, because they go to the fields (ladang). Residents' activities in the buruan imah (front cortyard) are chopping firewood, drying rice, clothing, and playing with children. During the full moon, the buruan imah is also busy, especially young children who play or teenagers who just sit on bamboo chairs until late at night. Activities in lolongkrang gede (alley) in addition to accessing residents from the side of the house, also for other activities, such as: chatting, playing with children, drying firewood, drying clothes, and so on. The most popular times for people to gather are in the afternoon until dusk (at 16.30-17.50). After sunset, the activity resumed until the evening time (at 19.00-20.30), even the men talked late into the night (at 22.00-01.30). In the kitchen of Bumi Ageung (traditional house), some residents still look busy watching television until dawn.

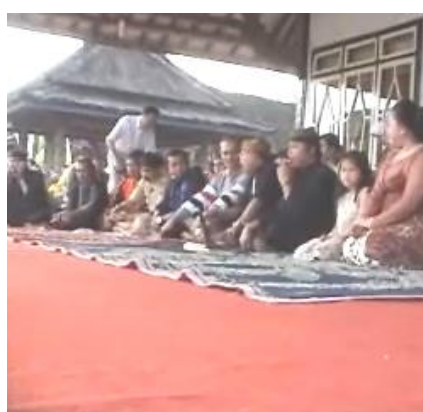

Tepas imah (terrace) is used to receive guests, chat, relax, etc.

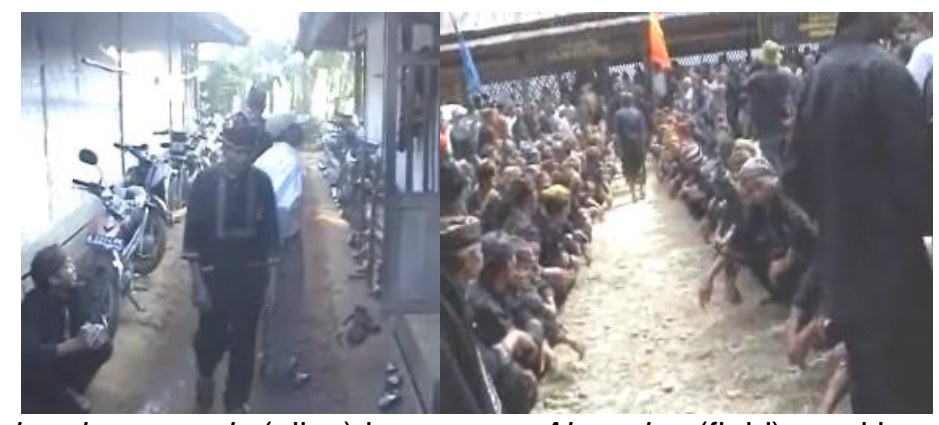

Lolongkrang gede (alley) is used as a place to store (parking area)
Alun-alun (field) used by Seren Taun traditional ceremonial processions

Nuryanto; Sri Rahaju B.U.K.; Indah Widiastuti | 39 
Figure. 2: The use of outdoor space during ceremonies of Seren Taun.

Source: Research tim, 2019

Public space as a physical object can simply be defined as space or form that is spatially utilized to accommodate joint activities. Public space can be planned or without planning. Functionally, public space is planned and designed deliberately to meet social and ritual interests. In the city, public space is designed as part of the physical aspects of the city that gives a visual orientation and even identity and creates a solid-void or positive-negative balance in an area as well as an embodiment of the democratic aspects of a place (Budihardjo, 1982; Budihardjo, 2009). The understanding of public space described above is normative as an object, but as a text, there arises the need to view the space as an accumulation of the contexts that make it happen. In the kampung Kasepuhan Ciptarasa and Ciptagelar, public spaces are used to accommodate daily life activities, especially during Seren Taun traditional ceremonies. Public spaces like this are indeed planned by traditional leaders for ceremonies, so they can accommodate many people (fig. 3 ).

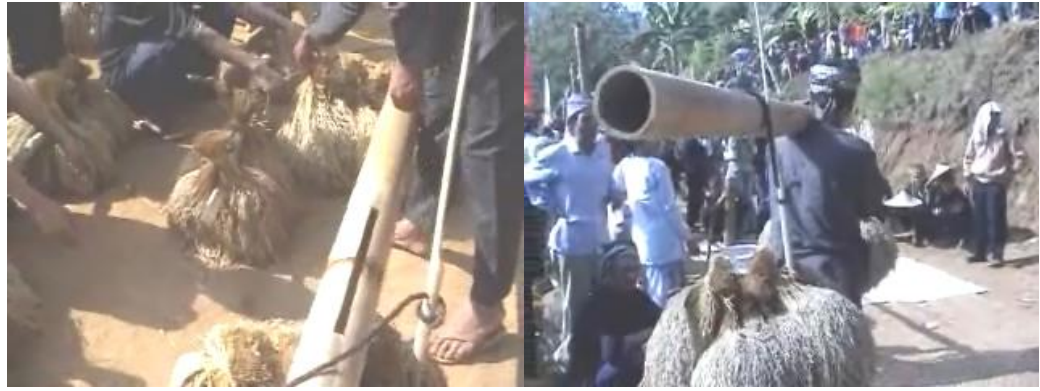

Tying rice in the field for ceremonial activities of Seren Taun

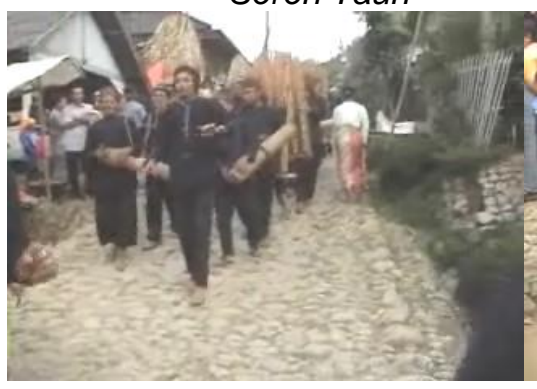

Village road is used by the parade of participants of the Seren Taun ceremony
Gathering in the village square to prepare for the Seren Taun ceremony

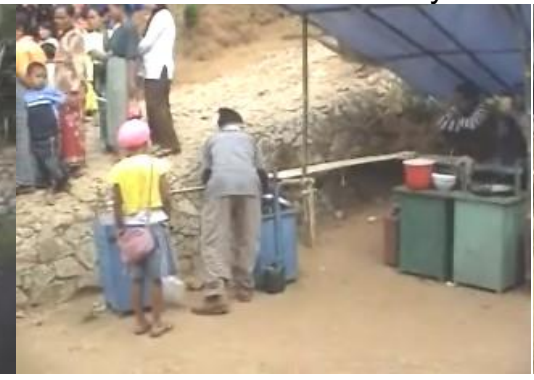

People use the curb to sell and watch the traditional paradeof Seren Taun

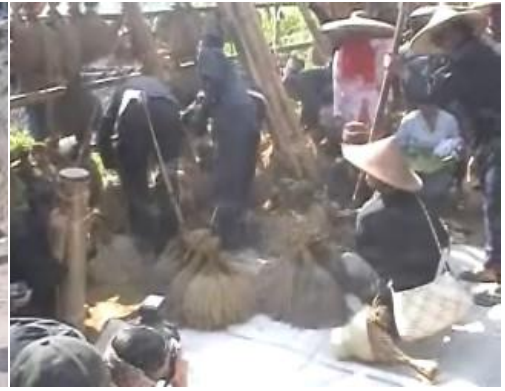

Collecting rice in the village square for the Seren Taun ceremony

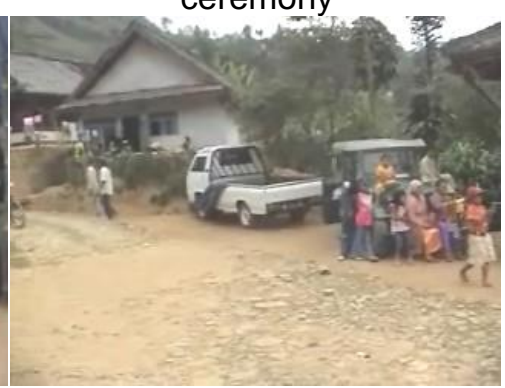

Part of roads are used for parking vehicles and watching of parade

Fig. 3: Community activities during Seren Taun traditional ceremonies. Source: Research tim, 2019

In this research, public space is seen in the context of event space or a link between various aspects that give birth to activities. Elementary aspects of the formation of events are as follows: First: Public participation, interaction, and activities have visible attributes that are marked by William Hollingsworth Whyte (Whyte, 1980) through events or the availability of (1) self-congestion: the tendency of people to interact in crowded places; (2) sitting spaces: or seating area; (3) the comfort factor of light, wind, water and very large trees; and (4) the existence of food vendors as a source of amenities. Gehl (1987) states that homogeneity is an element of encouraging participation. Hester (1979), said that social interaction is better when people feel they know each other. Second: In general, the nature of space, both outside and inside, can be planned in a design or formed by itself. As a forum for activities, "space" has two contexts (Whyte, 1980; Permana, 2011), namely: (1) effective environment: specially designed functional environment, (2) potential environment: various possible functions and activities that can be at any time according to the form of participation manifest during society. Third: Time is one of the variables occurring, or the intensity of the event in the space (Pataruka, 2018). 
Three elementary components of a public activity event space can be understood as forming elements of a public activity event in space. Differences in emphasis on one component of the text, be it space, time, or activity, or actors produce a context of public activity in a very diverse open space.

Specifically, the interwoven elementary components of the event space of public activities can be mapped through the following chart and coded through numbering K.1, K.2, and K.

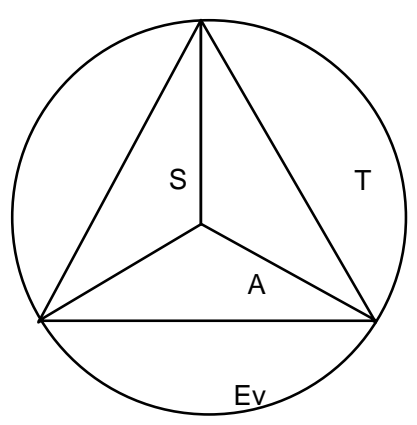

Chart 1: Forming components event space. Source: Research tim, 2019

$\begin{gathered}\text { Context of } \\ \text { public space events } \\ \text { K.1 Public open } \\ \text { of public space events }\end{gathered}$
space events that are
Emphed and then held.
organizers on activity
determinants as
activity

K.3 Public open
space events that occur
at certain times.
Emphasis on time as a
determinant

Chart 2: Interwoven elementary components of the event space of public activity. Source: Research tim, 2007

\subsection{Public Spaces and Event Texts at Kasepuhan Ciptarasa and Ciptagelar}

As a result of the structuring of the building period, the context of public space also has a very diverse realm, including public activity spaces as (1) Buildings where ordinary citizens gather or meet, are: First: Pawon bumi ageung; (2) Wawarungan or stalls; (3) Jamban or toilet (MCK), and (4) Saung lisung (a place to pound rice). Second: Places planned to accommodate joint activities, are: (1) Alunalun (field), and (2) Tajug (pray room). However, both places are rarely used as a gathering place except for special purposes. Third: The house is a private space that is accessible to public activities, including: (1) Bumi ageing; (2) Bumi tihang awi, or bumi tihang kalapa; (3) Imah baris kolot; (4) Imah patamuan, and (5) Imah warga. Fourth: Public and social facilities that are used for public purposes 
but are carried out by special actors relating to the functions of the social facilities are: (1) Pangkemitan; (2) Ajeng wayang golek; (3) Pangnyayuran; (4) Ajeng hiburan; (5) Leuit, (6) Bale adat kasepuhan; (7) Podium adat sesepuh girang, and (8) Saung lisung. From this tabulation, it can be understood that the function of the building period in the context of Sundanese society does not correlate with public-semi-public-private public consultation and sorting. Public spatial planning based on the placement of the building becomes irrelevant to the public activities that occur. For Sundanese people, public space may be used for any purpose, the concept of pemintakatan (zoning) is unknown because they hold the principle of "keur saha bae, keur naon bae", meaning for anyone and any purpose (Nuryanto, 2006). From this principle, it is clear that public space truly functions in a general and freeway. Nevertheless, at certain times it turns out that the public space is also used for its real function.

Table 1: Public intencities in building functions

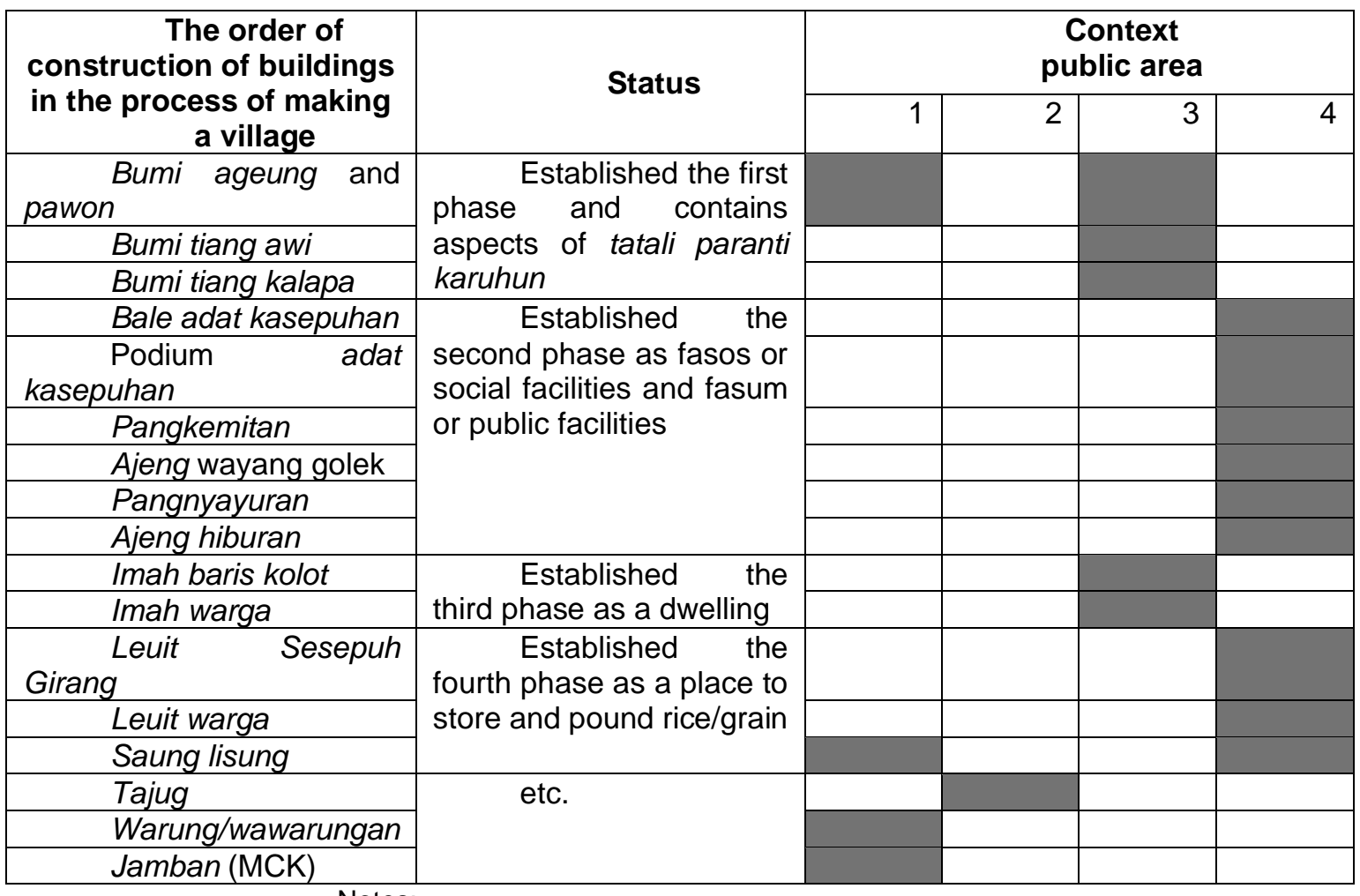

Notes:

(1) where ordinary people gathering or meeting;

(2) planned place to accommodate joint activities;

(3) accessible private place;

(4) accessible for spesial actors

Normatively, according to its type, the Sundanese community public space includes two types of scale, namely rohangan leutik (small space) and rohangan gede (big space). Rohangan leutik includes tepas imah (the front room of the house) where there are golodog (a kind of staircase going up the front of the house), and amben (hall), buruan imah (courtyard), pawon (kitchen), and lolongkrang imah (spaces between the sides home). Rohangan leutik spirit occurs as a consequence of the construction of houses by the builders. In this space, a variety of social activities often occur. Rohangan gede spirit is planned at the time of the founding of the village which is the result of an agreement between the elders (sesepuh) and their citizens (Nuryanto, 2006).

From the context of this understanding, it is clear that the big spirit is formal and belongs to the $\mathrm{K} 1$ text category while the rohangan leutik spirit is vernacular and informal and belongs to the K2 text category (see chart 4 interwoven elementary components of the event space of public activity). However, the high possibility of unexpectedness makes the rohangan leutik and rohangan gede spirits open to the K3 category braid model, ie activities that can occur at any time. Even the K3 text category model can be carried out outside the context of big or slow spirit like in the forest, rice fields, and barns. Empirically, the events of daily public activities can be described through emergent 
behavior settings (behavior settings are a combination of activity and a stable space). Some general behavioral settings that appear to display public activities with the following indicators: First: The intensity of daily activities in outdoor spaces increases in the morning at 6:00 to 08:00 and the afternoon at 15:00 to 18:00 (5 hours a day). Second: The intensity of daily activities in the outdoor space decreases during the day at $09.00-14.00$ and night above 19.00 (+/- 19 hours). Third: Pawon or kitchen of bumi ageing (home owned by elders who are the property of indigenous peoples) into a space in the house that is continuously accessible for residents and residents who visit for 24 hours, with activities to dwell, watch TV, mothers cook together, residents warm the body in front of hawu (fire stove), sleeping, talking, and children playing. Fourth: In an intensity that is not too high, wawarungan or stalls become a gathering place for residents in the morning and evening. Fifth: The intensity of public space activities is also characterized by traces and physical treatment of building exterior elements, such as storing activities outside the home.

In the context of high intensity of daily activities in outdoor space (K2 event text category), several general setting behaviors that appear in certain contexts, such as: First: Gathering while watching television. The settings that took place were: (a) a cooking place in the form of hawu (a furnace), with a television set on the back wall of the stall but still visible to the audience, a long seat; where the audience eats, sometimes the activity is filled with female and male visitors, but it never gets mixed up; (b). Gather in front of the house, which is usually done on the tepas imah, buruan imah, and golodog. Tepas imah is not too intensive to show public activities but physically the condition is always accessible and unlocked; (c). Roads in front of houses are usually used for gathering and chatting, children playing, passing motor vehicles while delivering things. The road in front of the house is not only an important tool for citizen accessibility, but also for social interactions that are carried out incidentally; (d). Store activities in the porch of the house especially carried out against the wall. The interior of the building is often empty but the exterior walls are filled with household utensils that are hung or propped up; (e). Pawon is not only used for cooking but also receive guests; (f). Chat together in the toilet (MCK) while bathing. There are no specific differences between women and men, but it is done in turns; (g). Buruan imah is made as a gathering place for chatting and playing regardless of age and gender.

At special times (K3 event categories) activities occur as follows: (a). The women gathered in the saung lisung to hitch while chatting; (b). At festivity, celebration or before fasting, pawon in the bumi ageung is usually an accessible space for anyone (women's space). They cook food for parties; (c). At special times sports events are held on the field; (d). Ngabotram (eating together) in open places; (e). At the Seren Taun ceremony, the courtyard is used as stalls for selling to seasonal traders; (f). Imah warga (privately owned houses) change their function as public during the Seren Taun ceremony, so that the bedrooms no longer function privately, but publicly, because anyone can go to sleep; (g). Abah Anom (traditional leader) and his wife carried out the tradition of ngadiukeun pare, which is to put rice in the leuit si Jimat (great granary) at the time of Seren Taun. After that, all people may start cooking rice which is the result of the harvest (nganyaran); (h). Abah Anom stood on the custom podium when giving announcements to the kasepuhan community; (i). Bale adat kasepuhan at the time of the ceremony was the audience seat.

Empirically, the events of special and traditional public activities, represented by Seren Taun and Ngaruwat Bumi activities. This Seren Taun and Ngaruwat Bumi program is traditional and becomes the image of the 'Imago Mundi' from the kampung Kasepuhan Ciptarasa and Ciptagelar, as well as being a bond between the people and their neighbors. Kasepuhan Ciptagelar becomes the 'Axis Mundi' of the whole kasepuhan ( $\mathrm{K} 1$ event category). At that time, public facilities that were not intensively utilized were utilized. In general, land use maps can be described as follows: (a). Alun-alun (main square), which is usually empty, the day before the traditional ceremony turns into a place for visitors passing by, the edge become a parking area for motorbikes and cars, some of which becomes a stall selling the work of residents. At traditional ceremonies, the square is transformed into a field for ceremonial participants, given clear territorial boundaries; (b). The schoolyard is a dangdut orchestra stage. Other vacant lots have become arenas for climbing and guest motorbike parking; (c). The roadsides and the courtyard turn into hawker stalls, clothes, fruits, and the whole street turns into night market alleys; (d). Tepas bumi ageung becomes a place for guests to watch wayang golek (puppet), eat and lie down; (e). The road out of the village was closed by the committee and changed into a place to hang rice ties tied to bamboo to form a long row before being transported to the ceremonial field; (f). Leuit (granary) belonging to the elder elves used as a place to hang animals (buffalo and goat) after being slaughtered, before being transported to the pawon bumi ageung (large kitchen); (g). Tepas imah warga (private terrace) are used as guest beds; 
(h). Pos ronda (security post) is used as a logistics warehouse to entertain guests and ceremony participants.

From the description of the name and scale of the space and its relation to imah (house) based on the understanding of the Kasepuhan Ciptarasa and Ciptagelar community, as well as the phenomenon of activities carried out by residents in their daily activities (social and ritual), tabulations can be made about the function of space in the context of Sundanese vernacular architecture like the table below:

Table 2: Use of space for public activities

\begin{tabular}{|c|c|c|c|c|c|c|c|c|}
\hline \multicolumn{2}{|c|}{$\begin{array}{c}\begin{array}{c}\text { Rohangan/ } \\
\text { space }\end{array} \\
\end{array}$} & \multicolumn{2}{|c|}{$\begin{array}{c}\text { Reference to } \\
\text { imah }\end{array}$} & \multicolumn{4}{|c|}{$\begin{array}{c}\text { Context } \\
\text { public area }\end{array}$} & \multirow[t]{2}{*}{ Information/note } \\
\hline Scale & Name & Jero & Jaba & 1 & 2 & 3 & 4 & \\
\hline & Tepas imah & V & & & & & & \\
\hline & Golodog & & V & & & & & \\
\hline $\begin{array}{l}\text { Rohangan } \\
\text { leutik }\end{array}$ & Amben & & V & & & & & \\
\hline \multirow[t]{3}{*}{$\begin{array}{l}\text { (vernacular } \\
\text {, informal) } \\
\end{array}$} & Pawon & V & & & & & & \\
\hline & Buruan imah & & V & & & & & \\
\hline & Lolongkrang & & V & & & & & \\
\hline $\begin{array}{l}\text { Rohangan } \\
\text { gede }\end{array}$ & Jalan & & V & & & & & \\
\hline \multirow[t]{3}{*}{$\begin{array}{l}\text { (planned, } \\
\text { formal) }\end{array}$} & Lapangan & & V & & & & & \\
\hline & Sampalan & & V & & & & & \\
\hline & Gawir & & V & & & & & \\
\hline
\end{tabular}

Notes:

(1) where ordinary people gathering or meeting;

(2) planned place to accommodate joint activities;

(3) accessible private place;

(4) accessible for spesial actors

From the table above, it can be mapped that all rooms, both inside and outside the house, small and large scale, are spaces where ordinary citizens gather or meet; or in other words, all rooms are rooms for public activities. The context of this public space is not only a space that is planned for a gathering place, but also a private space which is part of the family home, such as tepas, golodog, amben, buruan imah, lolongkrang imah, and pawon, which remain accessible for residents or even outsider. This is in accordance with the principle of their lives as members of the Banten Kidul indigenous community, namely "bengkung ngariung, bongkok ngaronyok", the meaning of living together, gathering and working together for mutual interests (Nuryanto, 2006).

\section{Conclusion}

Academically, this research has a very broad impact, because the phenomenon studied is not only how the visualization of public space in traditional society, but also the construct map and visual perception of the public space of traditional Indonesian society compared to the construct that has been taught in architecture schools, which more oriented towards Western standards. This difference is a trigger for more in-depth research on the context of public space design that is appropriate to the Indonesian climate, and then becomes the basis or technical reference for the design of Indonesian public spaces, which are more contextual, both for academic and technical purposes, among others:

1. The general principles of visual language elements of public space in Sundanese vernacular architecture are that spaces are compacted in space objects formed by landscape elements, traditions inhabiting outside the home before nightfall or before television;

2. Criticism of public space that is formally planned and appears as an independent object (space and form). Such spaces and shapes are usually designed to be a unifying space between building layouts, where humans interact. But in the Sundanese tradition, interaction is not carried out in a special way to come to this kind of space and form; interactions occur informally, as part of everyday life; 
3. Propose the prospect of its use in design in urban villages, flats, housing complexes, restaurants, and so on. In the design guidelines, it is necessary to include the character of the room with a high probability of success as a place for Sundanese interaction. From this research, the preferred public space is space related to daily life, is informal, human-scale, makes it easy to interact physically and visually, protected from the sun, not confined by walls, but instead is connected with nature;

4. The use of a public space for the people of kasepuhan, especially Ciptagelar, because of its ritual activities; Seren Taun ceremony and others. Outside the ritual, the function of public space is not visible. This reflects the position of the importance of the presence of public space only to facilitate its rite activities;

5. There are social values and ritual values that are reflected in public spaces in Kasepuhan Ciptagelar. Social values can be seen in the atmosphere of gathering between residents, both known and unknown, such as chatting on the tengah imah, lolongkrang imah, buruan imah, sampalan, alun-alun, and others. The value of the ritual can be seen from the Seren Taun ritual procession, such as reciting spells, the way to treat rice when it is inserted into the leuit si Jimat which is considered to be the incarnation of Dewi Sri (rice goddess), and so forth.

\section{References}

Budihardjo, E. (1982). Sejumlah Masalah Permukiman Kota (Edisi Pertama ed.). Bandung: Alumni. Budihardjo, E. (2009). Perumahan dan Permukiman di Indonesia. Bandung: Alumni.

Eriyanto. (2001). Analisis Wacana: Pengantar Analisis Teks Media. (Edisi Pertama ed.). Yogyakarta: LkiS.

Gehl, J. (1987). Life Between Buildings, (First Edition ed.). New York: Van Nostrand Reinbold Company.

Hester, R. T. (1979). Phenomenological Sociology (First Edition ed.). London: Sage Publication.

Nuryanto. (2006). Kontinuitas dan Perubahan: Pola Kampung dan Rumah dari Kasepuhan Ciptarasa ke Ciptagelar di Sukabumi Selatan, Jawa Barat. (Tesis Magister). Arsitektur SAPPK Institut Teknologi Bandung (ITB), Tidak dipublikasikan.

Pataruka, M. (2018). 'Ngalab Berkah' Pada Ruang Ritual Tradisi Dan Religi Masjid Agung Demak. Jurnal Arsitektur ZONASI, 1(2), 87. https://doi.org/10.17509/jaz.v1i2.12394

Permana, A. Y. (2011). Penerapan Konsep Perancangan Smart Village sebagai Local Genius Arsitektur Nusantara. Jurnal Arsitektur Komposisi, 9(1), 24-33.

Poespoprodjo, W. (1987). Beberapa Catatan Pendekatan Filsafatinya. (Edisi Pertama ed.). Bandung: Remaja Karya.

Spradley, P. J. (1980). Participant Observation (First Edition ed.). Florida: Holt, Rinehart and Winston von Eckartsberg, R. (1998). Existential-Ethnomethodology research. In R. Valle (Ed.), Inquiry in psychology (First Edition ed.). New York: Plenum.

Whyte, W. H. (1980). The Social Life of Small Urban Spaces, (First Edition ed.). Washington DC.: Conservation Foundation. 